\title{
Is PREVENT too toxic for feminists?
}

\section{Rahila Gupta*}

*Correspondence: rahilagupta@gmail.com

Well here we are again, confronted with yet another tightening of the government's noose around 'terrorists', 'non-violent extremists', 'radicals' - mostly synonyms for Muslim fundamentalists - which squeezes us, as secular feminists, into a space, the size of a postage stamp, in terms of our room for manoeuvre. The new look Prevent Programme is that noose

(c) (i) (2) ()

(C) Copyright: The Authors. This article is issued under the terms of the Creative Commons Attribution NonCommercial Share Alike License, which permits use and redistribution of the work provided that the original author and source are credited, the work is not used for commercial purposes and that any derivative works are made available under the same license terms. which is simultaneously too tight and too loose. It's a kind of saturation policing which does nothing to make us safer whilst being a brutal assault on the civil liberties of Muslim minorities as well as an assault on the rights of all those forced to help deliver the programme on pain of prison or fines. And most problematically for feminists, its racist targeting of Muslims is a propaganda gift to those religious forces whose world view is antithetical to women's rights and other minorities. Additionally, the borders between words such as, 'terrorists' and 'radicals' are being eroded by the almost interchangeable use of those words in public discourse; this is a dangerous development which undermines democracy but a discussion of this is beyond the scope of this essay.

\section{Background}

First a little history of Prevent, also known as Preventing Violent Extremism. It was introduced by the Labour government in the wake of 9/11 and 7/7 avowedly to foster the growth of moderate Muslim groups. The programme was funded to the tune of $£ 45 \mathrm{~m}$ over three years from 2008-2011, and was disbursed through local authorities to mainly Muslim groups to tackle radicalisation in their communities - one of the government's many contradictory attempts to cut down what it had pumped up with its other faith funding initiatives. How to define 
'moderate' is itself a minefield as we have seen in the on/off relationship between the government and the Muslim Council of Britain (MCB), for example, whose leaders had proven connections with religious extremists such as the Jamaat-e-Islami party on the Asian subcontinent. Besides as Pragna Patel of Southall Black Sisters (SBS) puts it, 'So called moderate religious groups may be moderate when it comes to bombing the streets of Britain but they are certainly not moderate when it comes to women' (as quoted in Gupta, 2010).

The Prevent programme was aimed at Muslim youth, women and mosques. According to Arun Kundnani (2009) who researched the earlier phase of Prevent while he was at the Institute of Race Relations, the sums of money given out were directly proportional to the size of the Muslim community in each area making it obvious that the Muslim community had been targeted as a 'suspect' community. After much criticism, the government announced that it would also sweep the far-right racist groups into its ambit.

Announcing the programme, Hazel Blears, the then Communities Secretary, said, 'resilient communities can only exist where women are playing a full and active part' (as quoted by Woolf, 2008). Women were to be empowered to challenge and head off extremism amongst Muslim youth. Their human rights were of no intrinsic worth despite the government's declarations to the contradictory. The government was playing the same game as religious fundamentalists - using women as a means of social engineering.

Little surprise then that Shaista Gohir (2010) of the National Muslim Women's Advisory Group resigned in protest because the government's policies were not actually empowering Muslim women who 'are one of the most disadvantaged groups in society, suffering the highest levels of economic inactivity, worst health and discrimination on multiple fronts.' However, the group's remit clearly involved advising the government on the role of women in preventing violent extremism which should have 
made the government's real agenda painfully clear from the start. Gohir found that the Prevent programme was being used to build up Muslim women to 'spy' on their families. This was confirmed by Arun Kundnani who found that 'a major part of the Prevent programme is the embedding of counter-terrorism police officers within the delivery of other local services...to facilitate the gathering of intelligence on Muslim communities' (2009: p.6). Furthermore, many organisations were told that they could not access the funds unless they were prepared 'to sign up to a counter-terrorism policing agenda'. One of Kundnani's interviewees reported that 'All the doors to obtaining funding for work with Muslim women were shutting and all the signposts were pointing to Prevent' (2009: p.19).

Gohir also pointed out the divisive nature of Prevent funding. She felt that other faith and secular women's groups were hostile towards Muslim women's groups as a result of Prevent funding being targeted towards them $^{1}$. She was right. Southall Black Sisters (SBS) found itself in that position when Ealing council threatened to withdraw our core funding. Although we worked across the entire spectrum of BME women, the Council chose to see us as a single ethnic group which undermined its interpretation of its cohesion duties while at the same time Prevent funding was being given out to Muslim Women's groups which were exclusive by definition. Ealing Council received between $£ 200,000$ and $£ 300,000$ from 2008-11 under Prevent; the Council made a grant of $£ 35,000$ to local groups to empower Muslim women and Youth services were given $£ 10,000$ to engage with Muslim girls in secondary schools through lunchtime sessions to discuss their concerns. Yet the very group that was empowering such women was being threatened with closure!

Secular women's groups are not hostile to Muslim women's groups per se, but to the idea that women should be defined primarily in terms of their religious identities when many of the issues - such as forced marriage and honour crimes - are faced by Muslim women in common with other 
minority women, and need to be fought on a common platform, precisely to avoid a racist perspective which equates one community with a particular practice.

Whilst the cohesion agenda, flawed as it was, claimed to promote race and gender equality, the 'fighting extremism agenda' definitely undermined it. A senior commander, Steve Allan, of the Metropolitan police said, in a conference on domestic violence in 2008, that the government's agenda on terror was hampering police work on forced marriage because the government was keen not to alienate those same leaders in the bigger fight against extremism.

\section{New Look Prevent}

The stick has displaced the carrot in Prevent, mark II. In 2011, the Coalition Government published its Prevent Strategy in which it described the previous strategy as flawed because, 'It confused the delivery of Government policy to promote integration with Government policy to prevent terrorism. It failed to confront the extremist ideology at the heart of the threat we face; and in trying to reach those at risk of radicalisation, funding sometimes even reached the very extremist organisations that Prevent should have been confronting' (HM Government, 2011: p.1). It's a fair critique. The Coalition's declared priority was to root out 'the ideology of extremism and terrorism' which left us in no doubt that the safeguarding of young people in danger of being radicalised was not its primary concern.

In the previous phase of Prevent, teachers, community workers, voluntary sector organisations resented having to share information with the police because they felt it was a breach of confidentiality and often refused to co-operate. To overcome this widespread resistance, the government has put Prevent on a statutory footing. Now these same workers are required to sit on Channel panels, a multi-agency forum, heavily populated by crime enforcement agencies: police, immigration 
officials, border force, prison officers, youth offending services. Monitoring of compliance with the Prevent Duty and the promotion of 'fundamental British values' will be part of Ofsted inspections ${ }^{2}$. A failure to comply, in the last resort, places the individual in contempt of court, which is punishable by imprisonment, a fine or both. British values remain ill-defined: a hostility to homosexuality is often equated with extremism yet Nicky Morgan MP, voted against gay marriage.

The advice issued by the Department for Education to schools and childcare providers specifically includes nursery schools. David Churchill (2015) reported that since September 2014, 400 under 18s, including teenagers and children, have been referred to the Channel process, the de-radicalisation programme at the heart of the Government's Prevent strategy ${ }^{3}$. These figures were obtained from the London Assembly. I stress the source as there have been attempts to discredit these figures on the basis that organisations with vested interests, like the Muslim Council of Britain (MCB) have been bandying these figures about. Children have been taken into care and a three-year-old child was placed on this scheme as part of a family group showing suspect behaviour. One wonders what benefit a three-year-old is likely to derive from the relatively benevolent sounding support plans under Channel, ranging from life skills training to mentoring and guidance on extremist ideologies. Why such mentoring could not be left to schools, youth services and any professionals who come into contact with young people without the intervention of police on the Channel panels is a question that remains unanswered. It is highly likely that the youngsters will remain on police records. In fact, there is no mention of recordkeeping in the government's (2015) document Channel Duty Guidance except for an ominous reference at the end of the document about what kind of information will be made available to the public under the Freedom of Information Act. Since 2012, more than 4,000 people have been referred, half of them under-18s - for showing signs of 'non-violent extremism'. A police study of 500 cases referred to Channel 
has found that 44 per cent of those referrals may have mental health issues which complicates the picture considerably (Dodd, 2016).

We have all heard the horror stories. A Muslim boy was taken out of class and questioned about his affiliation with ISIS after he used the word eco-terrorism in a debate in French on the environment (Dodd, 2015). Homa Khaleeli (2015) described a Prevent training video in which a teacher talks about a disquieting essay written by one of his students. He thinks she was 'struggling to fit in and not sure, culturally, where she belonged ... I am not suggesting she was going to support terrorism, but the opportunity was there if someone wanted to push her down that path.'

Of course, the horror stories provide ammunition to organisations like MCB in their critique of Prevent but the prospect of the MCB being in the same camp as us should not stop us from acknowledging the horror of these stories. Mona Eltahawy (2016) in Hymens and Headscarves describes the reaction to Aliaa Elmahdy, an Egyptian woman, who posted a picture of herself naked apart from a red hairclip, stockings and red shoes on her blog as a protest against sexual repression. Predictably she received vitriol from fundamentalists but more surprisingly she was condemned by liberals who we might have expected to support her. Liberals accused Aliaa of giving ammunition to religious conservatives. They will use any arguments that they can lay their hands on. We must never oppose anything simply because it furthers a reactionary agenda but because on principle we believe it to be wrong.

This kind of saturation policing is at work in immigration enforcement too where every imaginable social interaction requires a valid passport: from the health services to education providers to employers, landlords and marriage registrars. And the Immigration Enforcement hotline or the Anti-terrorism hotline are setting citizen against citizen. At one level, it's no surprise: immigrants and terrorists have often been collapsed into one category in the government's War on Terror narrative even though the narrative doesn't explain home grown terrorists e.g. 7/7 and those British 
Muslims going off to fight jihad. Forcing every section of society from private businesses to public sector workers to individual citizens to take on a 'crime enforcement' role, to do the state's dirty work, used to be a marker of authoritarian states where citizens were encouraged to spy and report on each other. It is also a consequence of neo-liberalism where the state is rolled back and its duties can no longer be adequately financed so vast sections of the population are roped in to do the work. But why is it that some of us find it easier to oppose the new immigration measures than we do Prevent? Is it because the anti-Prevent camp is congested with Islamists?

\section{Responding To Prevent}

We have many choices in how we respond to Prevent. We could take the line adopted by Inspire, the organisation that works with counterterrorism measures and tackles inequalities faced by Muslim women. They support the program wholeheartedly and run teacher training sessions in schools to allay fears about Prevent and keep 'children safely in their families'. Whilst I completely understand the heartbreak of parents standing helplessly by as their children are radicalised and disappear to certain death and whilst we do need to find ways to support them, I believe that an uncritical implementation of Prevent is a dangerous capitulation to state authoritarianism.

If the whole issue had been framed as a safeguarding of children issue, the programme would have received a warmer welcome from parents in need of support. This is not just a question of semantics but a shift of focus - where preventing harm to and protecting the child would have been of greater concern than their criminal potential and the impact of their future actions, as a consequence of their radicalisation, on the rest of society. The safeguarding framework is used to support children at risk of all kinds of harm be it FGM, forced marriage or sexual abuse. However, the guidelines to deal with these harms recommend training of professionals, emphasise their duties and responsibilities, team work and information sharing, not 
a prison sentence for failure to identify or report cases. Whilst mandatory reporting by professionals is required in 'known' cases of FGM, failure to comply will trigger professional disciplinary procedures not criminal proceedings. Nor is this duty applicable in cases of 'at risk' children, as in Prevent. There is no mandatory requirement to report children at risk of forced marriage either.

Having said that, even safeguarding policies are moving in the direction of criminalisation. Where child sexual abuse is concerned, there have been calls for tougher action from David Cameron ${ }^{4}$ and campaigns like Mandate Now ${ }^{5}$ run by the umbrella group, The Survivors' Trust, which demand that a failure to report should be a criminal offence. However, this demand is modified to exclude familial settings and only targets professionals suspected of malicious non-reporting 6 i.e. when they put the interests of their organisations above those of the child. Despite the general trend towards criminalisation, there is still a nuanced approach in safeguarding policy which says that professionals 'should' conform to certain standards which has been turned into a more draconian 'must' in the policies on Prevent.

The lack of trust engendered by the heavy-handed tactics of Prevent makes it counterproductive. Parents are less likely to approach professionals with concerns about the radicalisation of their children if it puts them on the government's radar rather than protects them. Rachel Shabi (2016) reported on a number of community initiatives which are run on a voluntary basis and aim to counter extremism among their young people, using history and reframing contemporary political questions. Suspicion of the authorities is so high that the very presence of this Guardian journalist reduced numbers by half at one of the sessions she attended. Those who run these counter-extremism programmes steer well clear of Prevent in the knowledge that their sessions will lose all credibility and impact among the young people they want to talk to. 
We could choose to condemn Prevent wholeheartedly as a letter signed by over 200 academics, published in The Independent did ${ }^{7}$. At one level, although I might quibble with its analysis of a number of issues including what drives people to 'terrorism', the letter should be supported. But this is where the issue of lack of political space for secular feminists arises. Our room for manoeuvre decreases by the day. Yes, as the letter says, Prevent will have a chilling effect on free speech and dissent but so does religious fundamentalism on women's right to dissent. However, the letter does not mention religious fundamentalism. The other issue raised by the letter was who initiated the process. Hidden among the signatories is a certain Asim Qureshi of CAGE, reminding us that the letter is a CAGE initiative - this is the same Qureshi who was unable to condemn the stoning of women for adultery under Sharia and whose support for the right to dissent is limited, conditional and far from universal. Do we want to give organisations like CAGE legitimacy by becoming signatories? This is a purely academic question because we were not asked as far as I am aware. But it is an important question in terms of tactics. Should we have signed that letter and then written our own one pointing out the political implications of the silences in the first letter?

SBS faced a similar situation when approached by Baroness Cox in 2012 who was seeking our support for her Arbitration and Mediation (Equality) Services Bill to curb the powers of religious courts especially in family matters. We had been campaigning against a parallel legal system for some time but Cox was a well-known Christian evangelist and therefore a problematic ally. Cox's Bill was targeted at the Muslim Arbitration Tribunals. It would create a new criminal offence of 'falsely claiming legal jurisdiction' for any person who adjudicates upon matters which ought to be decided by criminal or family courts.

We wanted to go further than her bill. So, we produced a briefing paper for Helena Kennedy so that she could put forward our position in the debate. SBS recommended that the use of any religious laws in family 
matters should be disallowed and that anyone seeking to arbitrate in family matters using religious laws should be criminalised. This proposal would sweep up sharia councils, MATs, the Beth Din and Catholic tribunals in its path, more than Baroness Cox would have bargained for. Cox's Bill fell at its second reading because the government refused to support it. It had been co-sponsored by the National Secular Society. I asked Keith Porteous Wood, Executive Director, whether he saw any contradictions in working closely with Cox. He said, 'We will work with anyone on a common agenda'. Was it tactically preferable to focus on a common agenda, to narrow it down to one religion as we were unlikely to win on longstanding religious courts like the Beth Din or Catholic tribunals or did the principle of not working with a religious conservative with an anti-Muslim focus transcend all other considerations?

Does the Cox affair give us any pointers on how to deal with Prevent? The problem is that Prevent hands religious fundamentalists a gift - a narrative of victimhood which makes it much harder for us to challenge them. It allows the powerful to parade in the clothes of the powerless and garner sympathy. We know there are global terror networks standing behind that façade. But to maintain a distance from and a critique of the anti-Prevent lobby, where it is led by religious fundamentalists, is a difficult juggling act when the task of opposing Prevent is so pressing. It was this difficult juggling act in relation to Moazzam Begg that led to the split and closure of Women Against Fundamentalism (WAF). The political triggers which marked the launch of WAF and its closure illustrate my point perfectly. The group was formed in support of Salman Rushdie and split on the question of Moazzam Begg. The political ground had shifted seismically since $9 / 11$. The government's condemnation of 'book-burning' Bradford Muslims at Rushdie's time in the 90s did not compare with state brutality against Begg and all the other War on Terror's crushing of civil liberties. And so, some members of WAF fell by the wayside as they could 
no longer tread the fine line between anti-racism and antifundamentalism.

By not standing up to Prevent unequivocally, it will appear as if we are relying on Prevent to do the work that we civil society actors should be doing and are doing - of fighting religious extremism wherever it rears its head - but also making our job harder by alienating communities, some of whom might well embrace extremism in response to their alienation.

Rahila Gupta is a freelance journalist and writer. Her work has appeared in Open Democracy, The Guardian and New Humanist among other papers and magazines. Her books include, Enslaved: The New British Slavery; From Homebreakers to Jailbreakers: Southall Black Sisters; Provoked; and Don't Wake Me: The Ballad of Nihal Armstrong. She is currently co-authoring a book with Beatrix Campbell with the title Why Doesn't Patriarchy Die? She has been an active member of the west London women's organisation Southall Black Sisters for over thirty years.

\section{References}

Churchill, D. (2015) 'London child aged THREE in terror alert over radicalisation' in The Evening Standard dated $27^{\text {th }}$ July 2015 and available at: http://www.standard.co.uk/news/london/london-child-aged-threein-terror-alert-over-radicalisation-10418455.html [Accessed 15/10/2015].

Dodd, V. (2015) 'School questioned Muslim pupil about Isis after discussion on eco-activism' in The Guardian dated 22 ${ }^{\text {nd }}$ September 2015 and available at:

http://www.theguardian.com/education/2015/sep/22/schoolquestioned-muslim-pupil-about-isis-after-discussion-on-eco-activism [Accessed 20/06/2017].

Dodd, V. (2016) 'Police study links radicalisation to mental health problems' in The Guardian dated 20 ${ }^{\text {th }}$ May 2016 and available at: 
http://www.theguardian.com/uk-news/2016/may/20/police-studyradicalisation-mental-health-problems [Accessed 20/06/2017].

Eltahawy, M. (2016) Headscarves and Hymens: Why the Middle East Needs a Sexual Revolution. London: W\&N.

Gohir, S. (2010) 'Muslim women are not political pawns' in The Guardian dated $9^{\text {th }}$ April 2010 and available at:

http://www.theguardian.com/commentisfree/2010/apr/09/governmentfailed-muslim-women [Accessed 20 June 2017].

Gupta, R. (2010) 'The religious lobby and women's rights' in Open Democracy dated $19^{\text {th }}$ April 2010 and available at:

https://www.opendemocracy.net/5050/rahila-gupta/religious-lobbyand-women\%E2\%80\%99s-rights [Accessed 19/04/2010].

HM Government (2011) Prevent Strategy, London: HMSO. Available at: https://www.gov.uk/government/uploads/system/uploads/attachment data/file/97976/prevent-strategy-review.pdf

HM Government (2015) Channel Duty Guidance, London: HMSO. Available at:

https://www.gov.uk/government/uploads/system/uploads/attachment data/file/425189/Channel Duty Guidance April 2015.pdf

Khaleeli, H. (2015) "'You worry they could take your kids": Is the Prevent strategy demonising schoolchildren?' in The Guardian dated $23^{\text {rd }}$ September 2015 and available at: http://www.theguardian.com/uknews/2015/sep/23/prevent-counter-terrorism-strategy-schoolsdemonising-muslim-children [Accessed 15/10/2015].

Kundnani, A. (2009) Spooked: How Not to Prevent Violent Extremism. London: Institute of Race Relations. Available at: http://www.irr.org.uk/pdf2/spooked.pdf

Shabi, R. (2016) 'Deradicalising Britain: the activists turning young Muslims away from extremism' in The Guardian dated $18^{\text {th }}$ March 2016 and available at: http://www.theguardian.com/uknews/2016/mar/18/deradicalising-britain-the-activists-turning-youngmuslims-away-from-extremism [Accessed 20/06/2017].

Woolf, M. (2008) 'UK gives millions to teach Muslim women confidence building and assertiveness skills "to curb terror"' in The Militant Islam Monitor dated $6^{\text {th }}$ January 2008 and available at: http://www.militantislammonitor.org/article/id/3309 [Accessed 15/10/2015]. 


\section{Notes}

${ }^{1}$ See 'OPEN LETTER - Resignation from the government's National Muslim Women's Advisory Group' at http://www.mwnuk.co.uk/news.php?id=58 [Accessed 13/06/2017].

${ }^{2}$ See ATL Advice on 'Understanding the Prevent Duty' at https://www.atl.org.uk/Images/adv84-understanding-prevent-duty.pdf [Accessed 15/10/2015].

${ }^{3}$ See HM Government's (2015) Channel Duty Guidance. London: HMSO. https://www.gov.uk/government/uploads/system/uploads/attachment data/fil e/425189/Channel Duty Guidance April 2015.pdf [Accessed 15/10/2015]. ${ }^{4}$ See Wintour, P. (2015) 'Jail those who turn a blind eye to child abuse says Cameron' in The Guardian dated 3rd March 2015 and available at:

http://www.theguardian.com/society/2015/mar/03/david-cameron-childabuse-ignore-jail [Accessed 1/06/2016].

${ }^{5}$ See: http://mandatenow.org.uk/wp-content/uploads/2014/08/5-minuteguide-to-MR-270714.pdf [Accessed 13/06/2017].

${ }^{6}$ See: http://thesurvivorstrust.org/news/mandate-response-nspcc-policyposition/ [Accessed 13/06/2017].

${ }^{7}$ The letter is available at:

http://www.independent.co.uk/voices/letters/prevent-will-have-a-chillingeffect-on-open-debate-free-speech-and-political-dissent-10381491.html [Accessed 16/10/2015].

\section{To cite this article:}

Gupta, R. (2017). Is PREVENT too toxic for feminists? Feminist Dissent, 2, 176-188. Retrieved from:

http://journals.warwick.ac.uk/index.php/feministdissent/article/view/24 